\title{
CHARACTERIZATION OF ASHES FROM FOREST BIOMASS COMBUSTION IN BOILERS: A SYSTEMIC VIEW OF POTENTIAL APPLICATIONS
}

\author{
Reny Aldo Henne ${ }^{1}$, Martha Andreia Brand ${ }^{2 *}$, Viviane Aparecida Spinelli Schein ${ }^{3}$, Ederson Rodrigues Pereira ${ }^{4}$, \\ Bianca Schveitzer ${ }^{5}$ \\ ${ }^{1}$ University of the State of Santa Catarina, Master's Program in Forest Engineering, Lages, Santa Catarina, Brazil - \\ renyhenne@hotmail.com, ${ }^{2 *}$ martha.brand@udesc.br \\ ${ }^{3}$ University of the State of Santa Catarina, Department of Sanitary and Environmental Engineering, Lages, Santa Catarina, Brazil - \\ viviane.schein@udesc.br \\ ${ }^{4}$ University of the State of Santa Catarina, Soil Department, Lages, Santa Catarina, Brazil - edersonquimica@gmail.com \\ ${ }^{5}$ EPAGRI, Experimental Station of Caçador, Caçador, Santa Catarina, Brazil - biancaschveitzer@ epagri.sc.gov.br
}

Received for publication: 28/08/2018 - Accepted for publication: 21/04/2019

\begin{abstract}
Resumo
Caracterização das cinzas produzidas na combustão da biomassa florestal em caldeira: um olhar sistêmico para potenciais aplicações. A descrição do processo de formação das cinzas durante a queima da biomassa e a determinação de suas propriedades físicas e energéticas são fundamentais para a melhoria dos processos de geração de energia e para a prospecção do reuso deste resíduo. Assim, o objetivo deste trabalho foi avaliar a qualidade energética da biomassa queimada e das cinzas geradas na caldeira de uma termelétrica que utiliza biomassa florestal como combustível, bem como considerar as aplicações potencias deste resíduo. Para este fim, foram determinadas as propriedades: teor de umidade; composição elementar orgânica e inorgânica; composição química imediata e poder calorífico superior nas cinzas em quatro pontos da caldeira (readler, tremonha, lavador de gases, decantador). Para efeito de comparação, a biomassa in natura foi calcinada em laboratório e avaliada juntamente com as cinzas provenientes da calcinação. A biomassa florestal utilizada na termelétrica, apesar de ser de origem residual apresentou alta qualidade energética, enquanto que as propriedades físicas, químicas e energéticas das cinzas produzidas na caldeira variaram em função das condições de operação da termelétrica. As cinzas coletadas na Tremonha tiveram elevado potencial energético, sendo necessários estudos de reconfiguração de fornalhas e tempo de retenção na câmara para possibilitar sua requeima eficiente visando seu aproveitamento energético. As cinzas da Tremonha têm potencial de uso como carvão vegetal para uso doméstico e como biocarvão. Os resultados produzidos são de fundamental importância e dão base para estudos mais aprofundados na área de requeima de cinzas, na produção de carvão vegetal para uso doméstico e como biocarvão.
\end{abstract}

Palavras-chaves: Biocarvão, carvão vegetal, requeima, termelétrica

\section{Abstract}

The description of the ash formation process during biomass burning and the determination of its physical and energetic properties are fundamental for the improvement of energy generation processes and the prospection of this residue's reuse. Thus, this study aimed to evaluate the energy quality of the biomass burned and the ash generated in the boiler of a thermal power plant that uses forest biomass as fuel, as well as to consider the potential applications of this residue. To this end, the following properties of the ashes collected at four different collection points of the boiler (readler, hopper, scrubber, and decanter) were determined: moisture content; organic and inorganic elemental composition; proximate composition; and gross calorific value. The biomass was calcined in the laboratory and evaluated together with the ashes from calcination to compare the results. Although the wood biomass used by the thermal power plant was a residual material, it presented high energy quality. The physical, chemical and energetic properties of the ashes produced in the boiler varied according to the thermal power plant's operation conditions. The ashes collected in the hopper showed a high energy potential, but further studies about furnace reconfiguration and retention time in the chamber are needed to allow its efficient burning for energy generation. Ashes from the hopper have the potential to be used as household charcoal and as biochar. The results obtained in this study are fundamentally important and provide a basis for further studies.

Keywords: Biochar, charcoal, reinjection in boiler; thermal power plant

\section{INTRODUCTION}

Knowledge of fuel's behavior is essential for a safe, stable and efficient design and operation of combustion equipment. It allows the customization of burning technologies, particularly when waste biomasses from industrial and energy crops are used, as their chemical composition behave differently from other types of biomass (LIU et al., 2012).

FLORESTA, Curitiba, PR, v. 50, n. 1, p. 1073 - 1082, jan/mar 2020.

Henne, R. A. et.al.

ISSN eletrônico 1982-4688 
During the burning of biomass, the formation of ashes occurs. The elements that form them are present in the biomass as salts that are chemically linked to the carbon structure (natural ashes). Ashes can also be aggregated to biomass as mineral soil particles that have been agglutinated during the plant's growth or during harvest and transport operations (contaminated ashes) (HANSEN; NYGAARD, 2014). Contaminated ashes' components are evenly distributed in the fuel and are much more portable than natural ashes' compounds, therefore, they react chemically during combustion (MERLINO et al., 2012). Also, waste biomasses from industrial processes and energy crops have higher ash contents including sodium, potassium, phosphorus, and chlorine, and a high ash content with a low melting point presents higher corrosion potential in burning equipment. (SHETH; BABU, 2010).

Thus, the chemical characterization of the composition of a particular solid fuel is the first and most important step of the investigation and application of such a fuel. This composition is a unique code that characterizes fundamental aspects and determines the properties, quality, potential applications and environmental problems related to any fuel. In this context, studies of physical and chemical properties have been used for characterizing solid fuels (VASSILEV; VASSILEVA, 2005). Analyzes traditionally used for characterizing solid fuels are: (1) proximate analysis (fixed carbon, volatile matter, ash and moisture contents); (2) organic elemental analysis $(\mathrm{C}, \mathrm{O}, \mathrm{H}, \mathrm{S}, \mathrm{N})$; (3) inorganic elemental analysis of ashes ( $\mathrm{Si}, \mathrm{Al}, \mathrm{Fe}, \mathrm{Ca}, \mathrm{S}, \mathrm{Mg}$, $\mathrm{K}, \mathrm{Ti}, \mathrm{Na}, \mathrm{P}$, occasional $\mathrm{Mn}, \mathrm{Cl}$, and trace elements) (VASSILEV; VASSILEVA, 2005).

In this regard, studies involving the description of the process of ash formation during the burning of residual biomass in burning systems of forest-based industries are fundamental in improving energy generation processes from this biofuel. Moreover, the physical, chemical, energetic and thermal characterization of combustion mineral wastes assists in prospecting the reuse of them in several applications, such as ash burning; using as other fuel products such as charcoal; improving some soil properties; water treatment, etc. Therefore, this study aimed to analyze the energy quality of the burnt biomass and the ashes generated in the boiler of a thermal power plant, which uses forest biomass as fuel, as well as to consider the potential applications of this residue.

\section{MATERIAL AND METHODS}

This study has been developed at a thermal power plant with a production capacity of $28 \mathrm{MW} /$ hour The power plant produces energy from the combustion of residual forest biomass coming from forest-based industries. It is located in Lages, Santa Catarina, Brazil (27 $\left.{ }^{\circ} 48^{\prime} 34.5^{\prime S} 50^{\circ} 22^{\prime} 34.9^{\prime \prime} \mathrm{W}\right)$. The generating unit is equipped with a furnace, an aqua tubular boiler with steam generation capacity of $120000 \mathrm{~kg} / \mathrm{h}$, the working pressure of $65.2 \mathrm{kgf} / \mathrm{cm}^{2}$, and controlled by a supervisory automation system; production of superheated steam with temperature around $485^{\circ} \mathrm{C}$, a superheater, an economizer and an air heater. The furnace is the place where the fuel burning takes place. It has 6 biomass feed points along its front wall and it's composed of a fixed type grid. The fuel is fed in the form of a layer of about 30 to $40 \mathrm{~cm}$ at the bottom of the boiler. Temperatures inside the furnace range from 800 to $1000^{\circ} \mathrm{C}$. During the combustion process, the heavy ashes fall by gravity to the bottom of the furnace in a water seal and they are extracted by a device called Readler (1) (Figure 1 (1)).

The light ashes (fly ashes) are dragged by the gases towards the superheaters at the top of the furnace. After this point, the ashes pass through the Hopper (Figure 1 (2)), which is a duct where there is also the extraction of ashes. Then, the ashes are conducted to the Pre-Air and Gas Scrubber (Figure 1 (3)), passing through a water seal and then collected and conducted to the vibratory sieve, which separates the heavy ashes from the light ones. The light ashes are routed to the Decanter (Figure 1 (4)), which pumps the ash fluid into a Washer Filter. The description of the collection points and the samples are presented in Table 1. To understand the changes that have occurred in the ashes at different times, the boiler's operating conditions have been described in three sample collection times (Table 2).

Table 1 - Description of the samples used for analyzing the biomass and the ashes Tabela 1 - Descrição das amostras utilizadas para análise da biomassa e das cinzas

\begin{tabular}{|c|c|c|}
\hline Sample & Collection point & Description of samples \\
\hline 1. Readler & Readler & Heavy ashes (Ashes, chips, and rocks) \\
\hline 2. Hopper & Hopper & Light ashes \\
\hline 3. Scrubber & Vibratory sieve & Moist ashes \\
\hline 4. Decanter & Concentrator filter exit & Fine and concentrated ashes \\
\hline 5. Biomass ashes & Calcined biomass & Sample treated under $1.000^{\circ} \mathrm{C}$ \\
\hline 6. Biomass & At the entrance to the boiler & Fuel \\
\hline
\end{tabular}




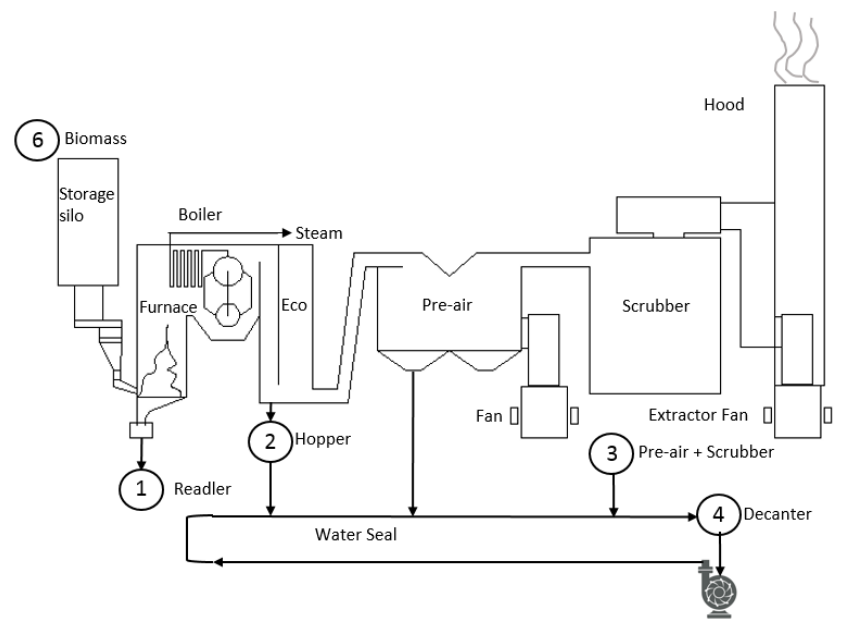

Figure 1 - Schematic representation of the flow of the combustion ashes of the biomass and the collection points of the analyzed samples in the boiler. The numbers 1, 2, 3, 4, and 6 represent, the Readler, the Hopper, the Pre-air and the Scrubber, the Decanter, and the biomass input into the boiler, respectively. Source: Henne et al. (2019).

Figura 1 - Representação esquemática da passagem das cinzas da combustão da biomassa e dos pontos de coleta das amostras analisadas na caldeira. Os números 1, 2, 3, 4 e 6 representam, respectivamente o Readler, Tremonha, Pré-ar e Lavador de gases, Decantador e a entrada da biomassa na caldeira. Fonte: Henne et al. (2019).

Table 2 - Boiler's operation parameters during sample collection

Tabela 2 - Parâmetros de operação da caldeira durante as coletas das amostras

\begin{tabular}{lrrr}
\hline Operation parameters & \multicolumn{2}{c}{ Sampling dates (2017) } \\
\hline Steam and water boiler & $\mathbf{0 5 / 3 1}$ & $\mathbf{0 8 / 0 8}$ & $\mathbf{1 1 / 1 4}$ \\
\hline Water intake flow ton/h & 66.4 & 91.2 & 89.10 \\
Steam flow (ton/h) & 64.1 & 91.3 & 89.3 \\
\hline Generator set & & & 20878.00 \\
\hline Active power kW & 12528.00 & 20976.00 & 5039.00 \\
Regenerative power kW & -1008.00 & 5376.00 & \\
\hline Air e Gases & & & 380.43 \\
Secondary air (inlet), mmca & 211.80 & 484.40 & 420.32 \\
Secondary air (Pre-air outlet), mmca & 202.80 & 469.90 & 33.83 \\
Primary air (Pre-air inlet), mmca & 30.24 & 35.59 & 34.33 \\
Primary air fan, mmca & 30.24 & 35.59 & 35.33 \\
Primary air fan, $\%$ & 34.03 & 46.00 & 394.05 \\
Secondary air fan, mmca & 211.0 & 484.40 & 0.38 \\
Secondary air fan, $\%$ & 0.18 & 0.40 & -15.39 \\
Pre-air gases inlet, mmca & -7.01 & -17.73 & -39.51 \\
Outlet pressure Echo, mmca & -24.52 & -51.87 & 40.85 \\
Exhaust fan 1 \% & 27.70 & 44.90 & 40.85 \\
Exhaust fan 2\% & 27.70 & 44.90 & \\
\hline
\end{tabular}

Sample 5 (Biomass ash) consisted of the calcination of the biomass collected before entering the boiler (sample 6) in the laboratory. This procedure has been carried out to allow the perfect combustion of the biomass, to obtain a material free or almost free of carbon, and to compare this ash with the ash produced in the boiler to verify the efficiency level of the industrial combustion. The calcination has been performed in a muffle furnace at $1,000^{\circ} \mathrm{C}$ for 3 hours, with a later cooling stage of about 6 hours.

We've collected $5 \mathrm{~kg}$ of each analyzed material to form a homogeneous sample. For all samples, the moisture content's been determined according to the NBR 14929 standard, in the condition of fresh material. After determining the moisture content, Readler biomass and ash samples were ground. All samples were sieved, and the sample portion that passed through the 40 sieve was retained in the 60 Mesh sieve.

FLORESTA, Curitiba, PR, v. 50, n. 1, p. 1073 - 1082, jan/mar 2020.

Henne, R. A. et.al.

ISSN eletrônico 1982-4688 
The analysis of the organic elements of the samples has been performed by a PerkinElmer CHNS elemental analyzer, model 2400. Based on the classic Pregl-Dumas method, the samples have been burned in a pure oxygen environment, with the resulting combustion gases being automatically measured. For the inorganic elemental analysis, the sample preparation procedure consisted of weighing $100 \mathrm{mg}$ of each sample. Then add 3 $\mathrm{mL}$ of $\mathrm{HNO}_{3}$ and $2 \mathrm{ml}$ of concentrated HCL to each sample for initial digestion with a $5 \mathrm{~h}$ resting time. After that, $2 \mathrm{ml}$ of $30 \% \mathrm{H}_{2} \mathrm{O}_{2}$ has been added to the resulting sample which was then subjected to the heating program using microwave radiation (Anton Paar Multiwave 3000). After cooling, the samples were transferred to $50 \mathrm{ml}$ tubes and centrifuged for phase separation. After the centrifugation step, the liquid part was transferred to $50 \mathrm{ml}$ tubes and then diluted with deionized water to complete $50 \mathrm{ml}$. The solid part was treated with the addition of 2 $\mathrm{ml}$ of $40 \% \mathrm{HF}$ and kept for 5 hours without heating. Then $20 \mathrm{ml}$ of $4 \% \mathrm{H}_{3} \mathrm{BO}_{3}$ was added to it to neutralize the residual acid. Next, it was transferred to tubes and diluted with deionized water to complete $50 \mathrm{ml}$. These solutions resulting from the supernatant and the solid part were analyzed by an optic emission spectrophotometer with plasma inductively attached to it (PerkinElmer Model Optima 8300), to determine the inorganic elemental composition.

Proximate analysis has been performed by a thermogravimetric scale, according to the ASTM 1762 standard, with temperatures of $900^{\circ} \mathrm{C}$ (volatile content) and $700^{\circ} \mathrm{C}$ (ash content). The determination of the gross calorific value has been carried out according to the DIN 51900 standard by an IKA C2000 model heat pump.

All the analyses have been performed in triplicate for each sample to obtain the means and coefficients of variation. After the application of the ANOVA, we used the Scott Knott test at a confidence level of 95\%. To determine the degree of linear correlation between the energy properties (calorific value, proximate chemical composition and organic elemental chemical composition), we used the Pearson's correlation coefficient (r), which reflects the intensity of the linear relationship between two data sets.

\section{RESULTS}

The results from the physical, chemical and energetic analyzes of the biomass and the ashes from both lab calcination and ashes from the boiler's collection points are presented in Table 3.

Table 3 - Physical, chemical and energetic properties of the biomass and the ashes produced in the combustion process in the boiler and the laboratory

Tabela 3 - Propriedades físicas, química e energéticas da biomassa e das cinzas produzidas no processo de combustão em caldeira e em laboratório

\begin{tabular}{|c|c|c|c|c|c|}
\hline Moisture content (\%) & Sampling 1 & Sampling 2 & Sampling 3 & Mean & CV (\%) \\
\hline Biomass & $60.14 \mathrm{a}$ & $53.71 \mathrm{~b}$ & $54.75 \mathrm{~b}$ & $56.20 \mathrm{C}$ & 2.15 \\
\hline Readler & $37.84 \mathrm{a}$ & $14.76 \mathrm{~b}$ & $26.74 \mathrm{~b}$ & $26.45 \mathrm{D}$ & 12.95 \\
\hline Hopper & $0.24 \mathrm{a}$ & $0.19 \mathrm{a}$ & $0.14 \mathrm{a}$ & $0.19 \mathrm{E}$ & 19.05 \\
\hline Scrubber & $86.76 \mathrm{~b}$ & $94.00 \mathrm{a}$ & $84.44 \mathrm{c}$ & $88.40 \mathrm{~A}$ & 0.59 \\
\hline Decanter & $57.26 \mathrm{~b}$ & $81.83 \mathrm{a}$ & $56.33 \mathrm{~b}$ & $65.14 \mathrm{~B}$ & 2.35 \\
\hline $\mathrm{CV}(\%)$ & & & \multicolumn{3}{|c|}{16,28} \\
\hline Gross calorific value (kcal/kg) & Sampling 1 & Sampling 2 & Sampling 3 & Mean & CV (\%) \\
\hline Biomass & $4777 \mathrm{a}$ & $4804 \mathrm{a}$ & $4754 \mathrm{a}$ & $4778 \mathrm{C}$ & 1.94 \\
\hline Readler & $823 \mathrm{a}$ & $482 \mathrm{~b}$ & $415 \mathrm{~b}$ & $573 \mathrm{E}$ & 10.27 \\
\hline Hopper & $4922 \mathrm{~b}$ & $4922 \mathrm{~b}$ & $6282 \mathrm{a}$ & $5375 \mathrm{~B}$ & 5.90 \\
\hline Scrubber & $7180 \mathrm{~b}$ & $7425 \mathrm{~b}$ & $7687 \mathrm{a}$ & $7431 \mathrm{~A}$ & 1.78 \\
\hline Decanter & 2998 c & $3967 \mathrm{a}$ & $3654 \mathrm{~b}$ & $3540 \mathrm{D}$ & 1.85 \\
\hline Biomass ashes & 0 & 0 & 0 & $0 \mathrm{~F}$ & 0 \\
\hline $\mathrm{CV}(\%)$ & & & \multicolumn{3}{|c|}{10,29} \\
\hline Fixed carbon content $(\%)$ & Sampling 1 & Sampling 2 & Sampling 3 & Mean & $\mathrm{CV}(\%)$ \\
\hline Biomass & $18.82 \mathrm{a}$ & $19.16 \mathrm{a}$ & $19.29 \mathrm{a}$ & $19.09 \mathrm{C}$ & 3.43 \\
\hline Readler & $3.51 \mathrm{a}$ & $3.12 \mathrm{a}$ & $4.44 \mathrm{a}$ & $3.41 \mathrm{D}$ & 23.2 \\
\hline Hopper & $63.02 \mathrm{a}$ & $58.40 \mathrm{~b}$ & $60.42 \mathrm{~b}$ & $60.62 \mathrm{~A}$ & 2.07 \\
\hline Scrubber & $75.08 \mathrm{a}$ & $68.78 \mathrm{~b}$ & $46.53 \mathrm{c}$ & $63.46 \mathrm{~A}$ & 2.3 \\
\hline Decanter & $29.36 \mathrm{a}$ & $29.51 \mathrm{a}$ & $29.37 \mathrm{a}$ & $29.42 \mathrm{~B}$ & 1.29 \\
\hline Biomass ashes & $0.33 \mathrm{~b}$ & $0.79 \mathrm{a}$ & $0.59 \mathrm{a}$ & $0.57 \mathrm{D}$ & 24.66 \\
\hline $\mathrm{CV}(\%)$ & & & \multicolumn{3}{|c|}{18,53} \\
\hline Volatile content (\%) & Sampling 1 & Sampling 2 & Sampling 3 & Mean & CV (\%) \\
\hline \multicolumn{6}{|c|}{$\begin{array}{r}\text { FLORESTA, Curitiba, PR, v. 50, n. 1, p. } 1073-1082 \text {, jan/mar } 2020 \\
\text { Henne, R. A. et.al } \\
\text { Electronic ISSN 1982-4688 } \\
\text { DOI: } 10.5380 / \text { rf.v50 i1. } 61229\end{array}$} \\
\hline
\end{tabular}




\begin{tabular}{|c|c|c|c|c|c|}
\hline Biomass & $80.22 \mathrm{a}$ & $80.29 \mathrm{a}$ & $79.33 \mathrm{a}$ & $79.95 \mathrm{~A}$ & 0.83 \\
\hline Readler & $18.31 \mathrm{a}$ & $14.15 \mathrm{a}$ & $7.73 b$ & $13.40 \mathrm{D}$ & 16.33 \\
\hline Hopper & $24.70 \mathrm{a}$ & $25.87 \mathrm{a}$ & $24.21 \mathrm{a}$ & $24.93 \mathrm{~B}$ & 9.07 \\
\hline Scrubber & $21.20 \mathrm{~b}$ & $25.24 \mathrm{a}$ & $27.49 \mathrm{a}$ & $24.64 \mathrm{~B}$ & 5.32 \\
\hline Decanter & $17.19 \mathrm{~b}$ & $21.30 \mathrm{a}$ & $17.26 \mathrm{~b}$ & $18.58 \mathrm{C}$ & 3.19 \\
\hline Biomass ashes & $0.70 \mathrm{~b}$ & $1.49 \mathrm{a}$ & $0.53 \mathrm{~b}$ & $0.90 \mathrm{E}$ & 34.85 \\
\hline CV $(\%)$ & & & \multicolumn{3}{|c|}{9,94} \\
\hline Ash content (\%) & Sampling 1 & Sampling 2 & Sampling 3 & Mean & CV (\%) \\
\hline Biomass & $0.96 \mathrm{a}$ & $0.56 \mathrm{~b}$ & $1.26 \mathrm{a}$ & $0.93 \mathrm{E}$ & 20.66 \\
\hline Readler & $78.18 \mathrm{~b}$ & $82.80 \mathrm{a}$ & $85.48 \mathrm{a}$ & $82.15 \mathrm{~B}$ & 2.83 \\
\hline Hopper & $12.27 \mathrm{c}$ & $14.44 \mathrm{~b}$ & $31.14 \mathrm{a}$ & $19.28 \mathrm{D}$ & 4.68 \\
\hline Scrubber & $3.72 \mathrm{a}$ & $4.51 \mathrm{a}$ & $3.11 \mathrm{a}$ & $3.78 \mathrm{E}$ & 29.93 \\
\hline Decanter & $53.44 \mathrm{a}$ & $48.94 \mathrm{~b}$ & $48.64 \mathrm{~b}$ & $50.34 \mathrm{C}$ & 1.04 \\
\hline Biomass ashes & $98.79 \mathrm{a}$ & $99.03 \mathrm{a}$ & $99.12 \mathrm{a}$ & $98.98 \mathrm{~A}$ & 0.24 \\
\hline $\mathrm{CV}(\%)$ & & & \multicolumn{3}{|c|}{9,68} \\
\hline Carbon (\%) & Sampling 1 & Sampling 2 & Sampling 3 & Mean & CV (\%) \\
\hline Biomass & $40.61 \mathrm{~b}$ & $35.50 \mathrm{c}$ & $58.76 \mathrm{a}$ & $44.96 \mathrm{C}$ & 3.72 \\
\hline Readler & $10.54 \mathrm{a}$ & $11.79 \mathrm{a}$ & $10.75 \mathrm{a}$ & $11.03 \mathrm{D}$ & 6.11 \\
\hline Hopper & $98.20 \mathrm{a}$ & $96.96 \mathrm{a}$ & $86.46 \mathrm{~b}$ & $93.87 \mathrm{~A}$ & 2.38 \\
\hline Scrubber & $68.45 \mathrm{c}$ & $75.34 \mathrm{~b}$ & $85.57 \mathrm{a}$ & $76.45 \mathrm{~B}$ & 2.78 \\
\hline Decanter & $75.61 \mathrm{a}$ & $24.87 \mathrm{~b}$ & $23.42 \mathrm{c}$ & $41.30 \mathrm{C}$ & 1.52 \\
\hline Biomass ashes & $8.60 \mathrm{a}$ & $5.98 \mathrm{~b}$ & $8.33 \mathrm{a}$ & $7.64 \mathrm{D}$ & 6.62 \\
\hline $\mathrm{CV}$ & & & \multicolumn{3}{|c|}{26,30} \\
\hline Hydrogen (\%) & Sampling 1 & Sampling 2 & Sampling 3 & Mean & CV (\%) \\
\hline Biomass & $7.84 \mathrm{a}$ & $6.01 \mathrm{a}$ & $7.42 \mathrm{a}$ & $7.09 \mathrm{~A}$ & 13.45 \\
\hline Readler & $0.73 \mathrm{~b}$ & $1.09 \mathrm{a}$ & $0.19 \mathrm{c}$ & $0.67 \mathrm{C}$ & 5.73 \\
\hline Hopper & $3.40 \mathrm{a}$ & $0.72 \mathrm{~b}$ & $3.13 \mathrm{a}$ & $2.41 \mathrm{~B}$ & 18.68 \\
\hline Scrubber & $2.28 \mathrm{a}$ & $2.38 \mathrm{a}$ & $2.48 \mathrm{a}$ & $2.38 \mathrm{~B}$ & 12.79 \\
\hline Decanter & $1.90 \mathrm{a}$ & $0.55 \mathrm{c}$ & $1.08 \mathrm{~b}$ & $1.18 \mathrm{C}$ & 7.16 \\
\hline Biomass ashes & $0.28 \mathrm{a}$ & $0.23 \mathrm{a}$ & $0.21 \mathrm{a}$ & $0.24 \mathrm{C}$ & 27.77 \\
\hline $\mathrm{CV}$ & & & \multicolumn{3}{|c|}{33,91} \\
\hline Sulfur (\%) & Sampling 1 & Sampling 2 & Sampling 3 & Mean & CV (\%) \\
\hline Biomass & $0.98 \mathrm{a}$ & $0.76 \mathrm{~b}$ & $1.02 \mathrm{a}$ & $0.92 \mathrm{~A}$ & 7.47 \\
\hline Readler & $0.19 \mathrm{a}$ & $0.15 \mathrm{~b}$ & $0.07 \mathrm{c}$ & $0.14 \mathrm{~B}$ & 4.26 \\
\hline Hopper & $0.40 \mathrm{a}$ & $0.06 \mathrm{c}$ & $0.24 \mathrm{~b}$ & $0.23 \mathrm{~B}$ & 9.89 \\
\hline Scrubber & $0.14 \mathrm{~b}$ & $0.19 \mathrm{~b}$ & $0.34 \mathrm{a}$ & $0.22 \mathrm{~B}$ & 27.84 \\
\hline Decanter & $0.24 \mathrm{a}$ & $0.02 \mathrm{~b}$ & $0.06 \mathrm{~b}$ & $0.11 \mathrm{~B}$ & 23.39 \\
\hline Biomass ashes & $0.49 \mathrm{a}$ & $0.04 \mathrm{~b}$ & $0.03 \mathrm{~b}$ & $0.19 \mathrm{~B}$ & 13.2 \\
\hline $\mathrm{CV}$ & & & \multicolumn{3}{|c|}{46,49} \\
\hline Nitrogen $(\%)$ & Sampling 1 & Sampling 2 & Sampling 3 & Mean & $\mathrm{CV}(\%)$ \\
\hline Biomass & $0.35 \mathrm{~b}$ & $0.30 \mathrm{c}$ & $0.44 \mathrm{a}$ & $0.37 \mathrm{~A}$ & 4.08 \\
\hline Readler & $0.00 \mathrm{~b}$ & $0.01 \mathrm{~b}$ & $0.03 \mathrm{a}$ & $0.01 \mathrm{C}$ & 72.98 \\
\hline Hopper & $0.20 \mathrm{~b}$ & $0.06 \mathrm{c}$ & $0.23 \mathrm{a}$ & $0.16 \mathrm{~B}$ & 4.11 \\
\hline Scrubber & $0.09 \mathrm{c}$ & $0.23 \mathrm{a}$ & $0.15 b$ & $0.16 \mathrm{~B}$ & 0.91 \\
\hline Decanter & $0.23 \mathrm{a}$ & $0.06 \mathrm{~b}$ & $0.07 \mathrm{~b}$ & $0.12 \mathrm{~B}$ & 25.47 \\
\hline Biomass ashes & $0.02 \mathrm{~b}$ & $0.02 \mathrm{~b}$ & $0.04 \mathrm{a}$ & $0.03 \mathrm{C}$ & 30.62 \\
\hline $\mathrm{CV}$ & & & \multicolumn{3}{|c|}{41,97} \\
\hline
\end{tabular}

Note: Means followed by the same letter do not significantly differ ( $\mathrm{P}=0.5$, Scott Knott test). The lowercase letters must be analyzed in the line, and the capital letters must be analyzed in the column. $\mathrm{CV}=$ coefficient of variation.

Figure 2 shows the relationships between $\mathrm{C} / \mathrm{N}$ and $\mathrm{H} / \mathrm{C}$ between the analyzed samples, and Table 4 presents the results obtained from the inorganic elemental analysis. Table 5 shows the correlation levels between the gross calorific value, the proximate chemical composition, and the organic elemental chemical composition

FLORESTA, Curitiba, PR, v. 50, n. 1, p. 1073 - 1082, jan/mar 2020.

Henne, R. A. et.al.

ISSN eletrônico 1982-4688 
obtained from the analyzes. These correlations are key to understand the behavior of the ashes within the boiler and to indicate possible uses for the waste generated from the biomass burning process in the boiler.

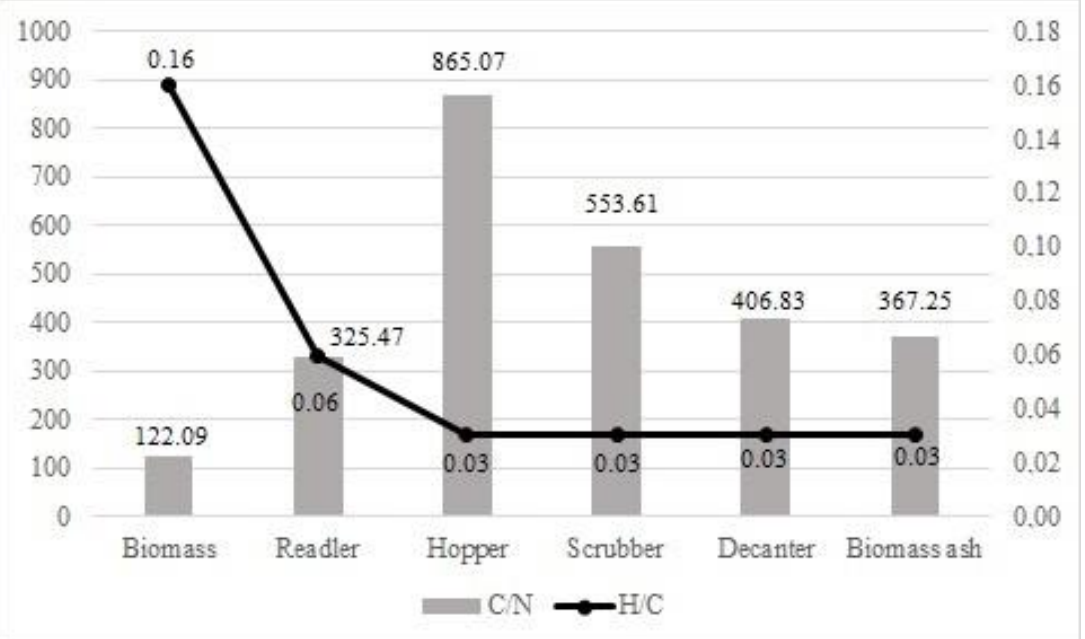

Figure 2 - Carbon/nitrogen $(\mathrm{C} / \mathrm{N})$ and hydrogen/carbon $(\mathrm{H} / \mathrm{C})$ ratios of the biomass and the ashes derived from its combustion (trocar virgulas por pontos e alterar os nomes - Biomass, Readler, Hopper, Scrubber, Decanter, Biomass ash)

Figura 2 - Relações carbono/nitrogênio (C/N) e hidrogênio/carbono (H/C) para a biomassa e as cinzas derivadas de sua combustão.

Table 4 - Inorganic elemental composition of ash samples (\%)

Tabela 4 - Composição elementar inorgânica das amostras das cinzas (\%)

\begin{tabular}{c|c|c|c|c|cc}
\hline Chemical element (\%) & Biomass Ash & Readler & Hopper & Scrubber & Decanter & CV \\
\hline $\mathrm{Al}$ & $4.97 \mathrm{a}$ & $3.86 \mathrm{~b}$ & $1.43 \mathrm{~d}$ & $0.19 \mathrm{e}$ & $3.09 \mathrm{c}$ & 26.43 \\
$\mathrm{Ca}$ & $4.65 \mathrm{a}$ & $2.38 \mathrm{~b}$ & $0.75 \mathrm{c}$ & $0.42 \mathrm{c}$ & $2.75 \mathrm{~b}$ & 22.51 \\
$\mathrm{Cr}$ & $0.026 \mathrm{a}$ & $0.006 \mathrm{~b}$ & $0.001 \mathrm{c}$ & $0.000 \mathrm{c}$ & $0.004 \mathrm{~b}$ & 43.67 \\
$\mathrm{Cu}$ & $0.026 \mathrm{a}$ & $0.008 \mathrm{~b}$ & $0.002 \mathrm{c}$ & $0.002 \mathrm{c}$ & $0.007 \mathrm{~b}$ & 38.82 \\
$\mathrm{Fe}$ & $5.64 \mathrm{a}$ & $4.93 \mathrm{a}$ & $1.47 \mathrm{c}$ & $0.129 \mathrm{~d}$ & $2.77 \mathrm{~b}$ & 26.1 \\
$\mathrm{~K}^{*}$ & $3.02 \mathrm{a}$ & $2.24 \mathrm{~b}$ & $0.64 \mathrm{~d}$ & $0.22 \mathrm{e}$ & $1.47 \mathrm{c}$ & 25.12 \\
$\mathrm{Mg}$ & $1.72 \mathrm{a}$ & $0.95 \mathrm{~b}$ & $0.31 \mathrm{c}$ & $0.15 \mathrm{c}$ & $0.87 \mathrm{~b}$ & 31.31 \\
$\mathrm{Mn}$ & $0.6 \mathrm{a}$ & $0.31 \mathrm{~b}$ & $0.09 \mathrm{c}$ & $0.04 \mathrm{c}$ & $0.36 \mathrm{~b}$ & 20.39 \\
$\mathrm{Na}$ & $0.00 \mathrm{a}$ & $0.00 \mathrm{a}$ & $0.00 \mathrm{a}$ & $0.0003 \mathrm{a}$ & $0.00 \mathrm{a}$ & - \\
$\mathrm{Pb}$ & $0.0003 \mathrm{a}$ & $0.0006 \mathrm{a}$ & $0.0004 \mathrm{a}$ & $0.0001 \mathrm{a}$ & $0.0006 \mathrm{a}$ & - \\
$\mathrm{Zn}$ & $0.028 \mathrm{a}$ & $0.002 \mathrm{~b}$ & $0.006 \mathrm{~b}$ & $0.007 \mathrm{~b}$ & $0.028 \mathrm{a}$ & 58.28 \\
$\mathrm{P}$ & $0.74 \mathrm{a}$ & $0.29 \mathrm{c}$ & $0.09 \mathrm{~d}$ & $0.03 \mathrm{~d}$ & $0.47 \mathrm{~b}$ & 22.46 \\
$\mathrm{Si}$ & $27.20 \mathrm{a}$ & $23.79 \mathrm{a}$ & $5.94 \mathrm{~b}$ & $3.32 \mathrm{~b}$ & $8.71 \mathrm{~b}$ & 36.92 \\
\hline
\end{tabular}

Note: Means followed by the same letter in line do not significantly differ ( $\mathrm{P}=0.5$, Scott Knott test); $\mathrm{CV}=$ coefficient of variation. *Obtained by using flame spectrophotometry.

Table 5 - Pearson's correlation coefficient between the analyzed variables

Tabela 5 - Coeficiente de correlação de Pearson para as variáveis analisadas.

\begin{tabular}{lllllll}
\hline Variables & GCV & VC & FC & AC & C & H \\
\hline GCV & - & 0,47 & 0,87 & $-0,93$ & 0,81 & 0,49 \\
VC & - & 0,10 & $-0,73$ & 0,25 & 0,94 \\
FC & & - & $-0,73$ & 0,87 & 0,16 \\
AC & & & - & $-0,76$ & $-0,71$ \\
C & & & & - & 0,33 \\
H & & & & & & - \\
\hline
\end{tabular}

Note: $\mathrm{GCV}=$ gross calorific value; $\mathrm{VC}=$ volatile content; $\mathrm{FC}=$ fixed carbono content; $\mathrm{AC}=$ ash content; $\mathrm{C}=$ elemental carbon; $\mathrm{H}=$ elemental hydrogen. 


\section{DISCUSSION}

The moisture content of the biomass varied among the samplings (Table 3), but it remained close to the percentage defined as the plant's operating parameter by the equipment's manufacturer (50\%) and the power plant's managers. Considering biomass as a fuel, the lower the moisture content, the higher the energy efficiency of the used material is (BRAND, 2010). In the Readler, the ashes' moisture content between the samplings varied from 15 to $38 \%$, and sampling 1 showed the highest moisture content. This is due to the heterogeneity of the material containing ashes, the partially carbonized biomass, and the contamination with stones, sand, and other debris.

In the Hopper, the samplings presented similar and more appropriate numbers to what was expected since they feature the light ashes derived from the combustion chamber which hadn't passed through the scrubber yet. The Scrubber and Decanter's samples had high moisture contents, which was expected because the ashes had already passed through the sealing water that transfers and decants the ashes from the collection points. However, there was a variation among the samplings from the same collection point, and the second sampling presented the highest moisture contents. After the ashes pass through the Decanter, the moisture content is significantly reduced. At this point, the ash is pressed between carrier rollers that draw some of the water from the material. The moisture content analysis of ashes is important in waste reuse projects: inside the plant in an ash reinjection system for burning or off-plant burning, to reuse residual carbon; for the removal, transport and off-site use in other applications or landfill disposal. There was a variation in the power plant's operation related to active power generation (Table 2), which increased from $12,528 \mathrm{~kW}$ in the first sampling to nearly $21,000 \mathrm{~kW}$ in samplings 2 and 3 . Thus, there was also a variation among the samplings in the amount of biomass that entered the system, and the ashes that came out in each step of the process.

The gross calorific value of the biomass was compatible with the average values observed for Pinus with bark reported by Brand (2010). There was no variation among the samplings (Table 3), which indicates that the biomass had constant quality throughout the power plant's operating time during the studied period (nearly 6 months). As the Readler is the first grid cleaning point, that is, where the heavy ashes are removed from the system and where there is a high level of contamination by foreign agents, it presented the lowest gross calorific value and the highest ash content among the evaluated collection points. There was a significant variation in gross calorific value from sampling 1 to samplings 2 and 3 at this collection point, being lower due to the higher ash content recorded at this point in the samplings 2 and 3.

In the Hopper, the increase in energy production (observed in samplings 2 and 3) (active power -Table 2) along with the increase in airflow and consequent increase in the volatilization of the gases carried to the Hopper caused the generation of more ashes. The fact that these ashes were not completely burned explains the higher calorific value observed for this residue in the sampling 3.

The ashes collected in the Scrubber presented the highest gross calorific values among the collection points. The increase in the production increased the generation of gases, which increased the dragging of materials that had suffered pyrolysis, but not complete combustion. The Scrubber's ashes had high energy quality and presented gross calorific values compatible with charcoal (Brand et al., 2015; Rosa et al., 2012). This indicates that if this material receives proper treatment, it could be used for power generation through re-burning. However, this re-burning or reinjection can't be done directly in the combustion chambers designed to burn biomass, as the furnace's residence time is different for this material containing high carbon content and light and small particles. Thus, before considering this possibility, studies aimed at reconfiguring the furnaces, in the case of co-burning, and studies of particle retention time in the combustion chamber are essential. The variations observed in the gross calorific value of the Decanter's ashes were caused by the same reasons. The values were low and only higher than the Readler's ones.

The biomass ash's gross calorific value was zero. It presented fixed carbon and volatile contents lower than $1 \%$, and ash content higher than $99 \%$. These numbers prove that the calcination in the laboratory was very efficient. This material was used in this study to accurately determine the inorganic elemental chemical composition of the ashes, and it was used to compare the results to the numbers from the literature. In general, the variation found for the gross calorific value of the materials collected at different points of the boiler and the fresh biomass shows that the boiler's burning process and the ashes' cleaning steps contributed to the changes observed among the analyzed materials.

Regarding the proximate analysis (Table 3), the biomass and the Readler and Decanter's ashes did not show changes in the fixed carbon contents among the samplings. Among them, the Decanter's ash had the highest fixed carbon content. The Hopper and Scrubber's ashes had similar fixed carbon contents and the highest average fixed carbon contents among the collection points. As expected, the fixed carbon content of the biomass ash did not exceed $1 \%$ due to the high burning efficiency obtained in the muffle furnace.

FLORESTA, Curitiba, PR, v. 50, n. 1, p. 1073 - 1082, jan/mar 2020.

Henne, R. A. et.al.

ISSN eletrônico 1982-4688

DOI: $10.5380 /$ rf.v50 i1.61229 
Concerning the volatile content, only the biomass and the Hopper's ashes did not vary among the samplings. The proximate chemical composition of the biomass was compatible with the values mentioned by Saidur et al. (2011) and Masiá et al. (2007), but with lower ash contents than those mentioned by these authors, confirming the high quality of the residual biomass used for energy generation at the power plant.

The Readler and Decanter's ashes showed the highest ash contents, indicating that the grid's cleaning is removing most of the inorganic contaminants from the biomass during the burning in the furnace and the Decanter is retaining the heaviest particles of the ashes' inorganic constituents. Although around $30 \%$ of fixed carbon remains in this ash fraction.

The results of the proximate chemical analysis indicate that the ashes collected in the Scrubber had suitable features to be used as charcoal in homes and as biochar. The disadvantage of the other collection points was the high ash content, which in any reuse will result in more waste generation.

Biochar is the solid product of the thermochemical conversion of biomass utilizing pyrolysis, gasification, roasting or hydrothermal carbonization (WEBER; QUICKER, 2018). It can have many environmental applications, such as in removing pollutants, in carbon sequestration, in soil fertility enhancement, in crop production and nutrient retention, and used as a recalcitrant carbon stock (OLIVEIRA et al., 2017). Weber and Quicker (2018) analyzed the biochar's properties for different applications. The data presented by these authors for wood biochar, carbonized above $700{ }^{\circ} \mathrm{C}$, were of above $90 \%$ fixed carbon content, 5 to $20 \%$ volatile content, and 1 to $7 \%$ ash content. As for the elemental chemical composition, they were of 60 to $90 \%$ carbon, less than $1 \%$ hydrogen, less than $0.5 \%$ nitrogen, and $\mathrm{H} / \mathrm{C}$ ratio from 0.1 to 0.3 . Vaughn et al. (2015), when analyzing biochar produced from trees managed in the coppice system of thirteen tree species, found values ranging from 3.1 to $9.5 \%$ of ash content. Regarding the elemental chemical composition, the authors obtained values ranging from 69.89 to $76.51 \%$ of carbon, 1.22 to $3.06 \%$ of hydrogen, 0.15 to $0.70 \%$ of sulfur, 0.39 to $1.34 \%$ of nitrogen, and an $\mathrm{H} / \mathrm{C}$ ratio ranging from 0.20 to 0.51 . Lan et al. (2018), when analyzing pine biochar at different temperatures, found values of 0.14 to $0.24 \%$ of ash content, 62.4 to $72.3 \%$ of carbon, 0.09 to $0.14 \%$ of nitrogen, and a C / $\mathrm{N}$ ratio from 514 to 870 .

The elemental chemical characterization is very important because the hydrogen and the carbon affect positively the gross calorific value of materials. On the contrary, oxygen affects it negatively. The sulfur and nitrogen negatively affect human health and the environment (Rosa et al., 2012). As for the organic chemical composition (Table 3), the elemental carbon content did not vary only among the Readler's samplings, which together with the biomass ashes presented the lowest values. The highest carbon content was observed in the Hopper, followed by the Scrubber, the Biomass, and the Decanter. The Hopper and Scrubber's ashes presented carbon contents similar to the ones found in charcoal obtained from wood pyrolysis in masonry heaters for both steel and domestic uses. The elemental chemical composition of eucalyptus charcoal reported by Carvalho et al. (2014) was 79.81 to $81.60 \%$ of carbon content, 3.27 to $3.42 \%$ of hydrogen, 0.16 to $0.25 \%$ of nitrogen, and 0.02 to $0.04 \%$ of sulfur.

These high elemental carbon contents are allied to the fact that these collection points also have higher gross calorific values and high levels of fixed carbon, which give these ashes properties that characterize this material for energy use as household charcoal. Brand et al. (2015) and Rosa et al. (2012) carried out studies of household charcoals and obtained results similar to the ones found in this study. To turn this product into a biofuel that is easier to transport and store, briquetting or pelletizing studies should be developed in a sense of promoting the binding of this material. Besides, there is a need for studies to analyze the potential of the use of this material as biochar in the treatment of water and soil pollutants.

The hydrogen contents of the Biomass, the Scrubber ashes, and the Biomass ashes did not vary among the samplings. As expected, the Biomass had the highest hydrogen content, around 6 to $8 \%$, which is close to the values reported by Saidur et al. (2011) and Masiá et al., (2007). The hydrogen contents of the Hopper and the Scrubber ashes were similar to the ones found by Carvalho et al. (2014) in charcoal. The lowest hydrogen contents were the ones from the Readler, the Decanter, and the Biomass ashes. Nitrogen and sulfur contents were fairly low for the Biomass and the ashes derived from its combustion, which represents one of the reasons why biomass burning is considered to have low potential to contribute to acid rain formation. The Biomass before the combustion presented the highest nitrogen and sulfur contents, however, they were below $1 \%$.

Santana et al. (2012) state that the $\mathrm{C} / \mathrm{N}$ (carbon/nitrogen) and $\mathrm{H} / \mathrm{C}$ (hydrogen/carbon) ratios are important parameters in the assessment of biomass energy. The $\mathrm{C} / \mathrm{N}$ ratio establishes the speed in which nitrogen returns to its natural cycle. The lower this ratio, the faster the $\mathrm{C}$ in the material in the form of $\mathrm{CO}_{2}$ is released. Also, it indicates the fuel's polluting potential due to the emission of nitrogen oxides, which result in acid rain. The $\mathrm{H} / \mathrm{C}$ ratio shows the energy release capacity. The higher the $\mathrm{H} / \mathrm{C}$ ratio, the more energetic the material is.

Moreover, the Hopper ashes presented the highest $\mathrm{C} / \mathrm{N}$ ratio which proves its high carbon uptake potential, a very important feature to be considered when using material as biochar. On the other hand, the 
Biomass presented the lowest values (Figure 2). The Hopper ashes would be best ashes suited for re-burning or re-injection systems to harness residual carbon and increase the biomass use for energy production. However, specific studies need to be carried out regarding this matter. Previous re-injection tests have been carried out at the thermal power plant and problems related to rock formation inside the boiler occurred. These problems happen due to the high elemental and fixed carbon contents of ashes that require longer residence time within the boiler and adjustments to the primary and secondary air supply. If biomass burning is conducted without considering these variations, the re-injection will cause more problems than benefits.

Regarding the inorganic elemental chemical composition, results show a variation in the elemental composition of the ashes from the different collection points (Table 4). The combustion temperature and the ashes' exposure time led to changes in the number of chemical elements along with the ash flow inside the boiler, except for sodium and lead which did not show significant amounts. At all collection points, the chemical elements that showed the highest concentrations were silicon, iron, aluminum, calcium, and potassium. They all had, without exception, their concentrations reduced throughout the process with a subsequent significant increase at the Decanter. According to Saidur et al. (2011), woody biomass has high Ca and K contents and low $\mathrm{Si}$ contents in ashes. High concentrations of $\mathrm{Si}, \mathrm{Fe}$, and $\mathrm{Al}$ were found in the analyzed samples, which confirms the existence of biomass contaminants such as earth, sand, and stones.

The Readler was the collection point that presented many chemical elements more similar to the biomass that enters the boiler (mainly $\mathrm{Si}$ and $\mathrm{Fe}$ ) as it is the first ash removal site and it has incombustible material. The Hopper, the Scrubber and the Decanter showed a significant reduction in Si contents, which were statistically similar to each other. The Hopper and Scrubber's ashes showed similar contents of $\mathrm{Ca}, \mathrm{Cr}, \mathrm{Cu}, \mathrm{Mg}$, $\mathrm{Mn}, \mathrm{Zn}$, and P. Furthermore, the Readler and Decanter's ashes presented similar contents of $\mathrm{Ca}, \mathrm{Cr}, \mathrm{Cu}, \mathrm{Mg}$, and $\mathrm{Mn}$. It is a common practice in the region to dispose of ashes in forest or agricultural areas for incorporating them into the soil. Thus, the chemical characterization of the ashes is fundamental when using ashes for fertilization and soil $\mathrm{pH}$ correction because it supports the decision-making process. It answers the question of whether or not this material will improve soil quality.

There was a positive correlation between the gross calorific value and the fixed carbon content, and between the gross calorific value and the elemental carbon content (Table 5). On the other hand, a negative correlation was found between the gross calorific value and the ash content. Since the calorific value indicates the energy potential of a material and the proximate chemical composition indicates the behavior during its burning process, it can be said that the ashes collected at the Scrubber is an excellent fuel because they have high gross calorific value, high fixed carbon content, and low ash content (Table 3). Therefore, they can be reused as an energy resource in the form of charcoal. Also, the ashes presented high elemental carbon content and low hydrogen content, enhancing the use of the ashes as biochar.

Also, the volatile content presented a high positive correlation with the hydrogen content and a high negative correlation with the ash content. Volatiles are the compounds that are burned in the gaseous form and are constituted of hydrocarbon compounds, which explains the high correlation between the two variables. The ash content of the inorganic residues, which did not participate in the combustion process, showed a high and inverse relationship with the energy properties of biomass (GCV, VC, and FC) and the elemental carbon and hydrogen contents. This is because the ash content is formed by inorganic compounds that bind with oxygen to form oxides and do not participate in the combustion process. In addition, the high positive correlation between the fixed carbon content and the elemental carbon content was also expected because the fixed carbon content is the wood fraction that burns as carbonaceous waste, but still retains its partially organized structural elements (cellulose, lignin, polyioses). The elemental carbon content expresses the amount of carbon regardless of the chemical bonding form, though.

\section{CONCLUSIONS}

- Forest biomass, despite being a residual source, presented high energy quality considering the project specifications and the boiler's operating conditions. The properties of the ashes produced from its combustion varied according to the operating conditions of the thermal power plant.

- The ashes collected at the Hopper have high energy potential and can be used in re-burning systems, for household charcoal production, and as biochar. The ones collected at the Scrubber can be used for household charcoal and as biochar. In the re-injection of the Hopper ashes for re-burning, further studies should take into account the high elemental carbon content and the lower burning rate concerning fresh biomass to avoid stone and scale formation in the boiler.

- When using ashes as biochar, analyzes of other important properties should be performed, such as the determination of the functional groups presented on the biochar's surface; $\mathrm{pH}$; cation exchange capacity; reactivity; thermogravimetric analysis; porosity; bulk density; true density; particle density; surface area;

FLORESTA, Curitiba, PR, v. 50, n. 1, p. 1073 - 1082, jan/mar 2020. 
pore volume; pore size distribution; hydrophobicity; water holding capacity; mechanical stability; thermal conductivity; electromagnetic shielding efficiency; and grinding and agglomeration potential.

- To use the boiler's ashes as charcoal, studies regarding the production of briquettes or pellets are important as the ashes are produced in the powder form.

\section{ACKNOWLEDGMENTS}

We thank the National Council for Scientific and Technological Development (Call CNPq No. 12/2017 - Research Productivity Scholarship PQ), FAPESC - "and the Santa Catarina State Research and Innovation Support Foundation (FAPESC) and the Company ENGIE S.A.

\section{REFERENCES}

BRAND, M. A. Energia de biomassa florestal. Rio de Janeiro: Editora Interciência, 2010, 114 p.

BRAND, M. A.; ALMADA RODRIGUES, A.; DE OLIVEIRA, A.; SILVEIRA MACHADO, M.; ZEN, L. R. Qualidade do carvão vegetal para o consumo doméstico comercializado na região serrana sul de Santa Catarina. Árvore, Viçosa, v.39, n. 6, p. 1165-1173, 2015.

CARVALHO, V. S.; BIANCHI, M. L.; TRUGILHO, P. F.; JÚNIOR PEREIRA, A.; HÖFLER, J. Correlações entre as propriedades da madeira e do carvão vegetal de híbridos de eucalipto. Árvore, Viçosa, v. 38, n. 3, 2014.

HANSEN, U. E.; NYGAARD, I. Sustainable energy transitions in emerging economies: the formation of a palm oil biomass waste-to-energy niche in Malaysia 1990-2011. Energy Policy, Washington, v.;66, p. 666-676, 2014.

HENNE, R. A.; BRAND, M. A.; SCHVEITZER, B.; SCHEIN, V. A. S. Thermal behavior of forest biomass wastes produced during combustion in a boiler system. Revista Árvore, Viçosa, v. 43, n. 1, p. 1-9, 2019.

LAN, Z.; CHEN, C.; REZAEI RASHTI, M.; HONG, Y.; ZHANG, D. High pyrolysis temperature biochars reduce nitrogen availability and nitrous oxide emissions from an acid soil. GCB Bioenergy, London, Accepted paper. https://doi.org/10.1111/gcbb.12529. Jun. 2018.

LIU, X.; WANG, W.; SHI, Y.; ZHENG, L.; GAO, X.; QIAO, W.; ZHOU, Y. Pilot-scale anaerobic co-digestion of municipal biomass waste and waste activated sludge in China: effect of organic loading rate, Waste Management, Raleigh v. 32, n. 11, p. 2056-2060, 2012.

MASIÁ, A. T.; BUHRE, B. J. P.; GUPTA, R. P.; WALL, T. F. Characterising ash of biomass and waste, Fuel Processing Technology, Western Australia, v. 88, n, 11, p. 1071-1081, 2007.

MERLINO, G.; RIZZI, A.; VILLA, F.; SORLINI, C.; BRAMBILLA, M.; NAVAROTTO, P.; DAFFONCHIO, D. Shifts of microbial community structure during anaerobic digestion of agro-industrial energetic crops and food industry byproducts, Journal of Chemical Technology Biotechnology, London, v.87, n. 9, p. 1302-1311, 2012.

OLIVEIRA, F. R.; PATEL, A. K.; JAISI, D. P.; ADHIKARI, S.; L U, H.; KHANAL, S. K. Environmental application of biochar: Current status and perspectives. Biores. technology, Lucknow, v. 246, n. 110-122, 2017.

ROSA, R. A.; CHAVES ARANTES, M. D.; PAES, J. B.; ANDRADE, W. S. D. P.; MOULIN, J. C. Qualidade do carvão vegetal para o consumo doméstico. Journal of Biotechnology and Biodiversity, Gurupi, v.3, n.2, p.4148, 2012.

SAIDUR, R.; ABDELAZIZ, E. A.; DEMIRBAS, A.; HOSSAIN, M. S.; MEKHILEF, S. A review on biomass as a fuel for boilers, Renewable and Sustainable Energy Reviews, Belfast v, 15, n, 5, p, 2262-2289, 2011.

SANTANA, W. M. S.; CALEGARIO, N.; ARANTES, M. D. C.; TRUGILHO, P. F. Effect of age and diameter class on the properties of wood from clonal Eucalyptus. Cerne, Lavras, v. 18, n. 1, p. 1-8, 2012.

SHETH, P. N.; BABU, B. V. Production of hydrogen energy through biomass (waste wood) gasification. International Journal of Hydrogen Energy, Coral Gables, v. 35, n. 19, p. 10803-10810, 2010.

VASSILEV, S.; VASSILEVA, C. Methods for characterization of composition of fly ashes from coal-fired power stations: a critical overview, Energy Fuels, Washington, v. 19, p.1084-1098, 2005.

VAUGHN, S. F.; KENAR, J. A.; ELLER, F. J.; MOSER, B. R.; JACKSON, M. A.; PETERSON, S. C. Physical and chemical characterization of biochars produced from coppiced wood of thirteen tree species for use in horticultural substrates. Industrial crops and products, St Martin d'Heres, v. 66, p. 44-51, 2015.

WEBER, K.; QUICKER, P. Properties of biochar. Fuel, Shaanxi, v. 217, p. 240-261, 2018. 